\title{
PEMBELAJARAN DARING LATSAR CPNS FROM HOME DALAM MASA PANDEMI COVID-19
}

\author{
Agus Suharsono \\ Balai Diklat Keuangan Yogyakarta \\ Email: gusharpramudito@gmail.com
}

\begin{abstract}
Abstrak
Penelitian ini bertujuan menganalisis pembelajaran Whole of Government melalui kelas daring pada Latsar CPNS From Home dalam masa pandemi COVID-19 di Balai Diklat Keuangan Yogyakarta. Metode yang digunakan adalah kuasi eksperimen. Hasil penelitian adalah sebagai berikut: hasil nilai post test rata-rata kelas adalah 92 atau sangat memuaskan, nilai per peserta tertinggi dengan nilai 100 atau sangat memuaskan dan terendah 81 atau memuaskan. Rancangan tindakan pembelajaran mampu menyampaikan materi sampai $81 \%-95 \%$. Kekurangan pembelajaran daring adalah kurangnya pemahaman materi dan kendala internet yang tidak stabil, sedangkan kelebihannya adalah menarik, menyenangkan, mengasah kecekatan diri dalam mencari dan menemukan jawaban. Saran perbaikan adalah menambah pembahasan materi pembelajaran, bentuk soal dengan pilihan jawaban benar-salah diganti pilihan ganda, dan mengurangi jumlah soal post test. Secara umum pembelajaran daring dinilai positif dan efektif oleh peserta sehingga dapat dilanjutkan baik pada masa pandemi maupun menjadi new normal.
\end{abstract}

Kata kunci : Pembelajaran daring, Latsar CPNS, COVID-19

\begin{abstract}
This study analyzes the learning of the Whole of Government through online classes at Latsar CPNS from Home during the COVID-19 pandemic at the Yogyakarta Financial Training Center. The method used is quasi experiment. The results of the study are as follows: the average post-test score of the class is 92 or very satisfactory, the highest score per participant with a score of 100 or very satisfying and the lowest is 81 or satisfying. The learning action plan is able to convey material up to $81 \%-95 \%$. The disadvantages of online learning are the lack of understanding of the material and the constraint of unstable internet connections, while the strengths are interesting, fun, sharpening your dexterity in searching and finding answers. Suggestions for improvement are to add to the discussion of learning material, the form of questions with right-wrong answer choices be replaced by multiple choices, and reduce the number of post-test questions. In general online learning is considered positive and effective by participants so that it can be continued both during the pandemic and the new normal.
\end{abstract}

Keywords : Online learning, Latsar CPNS, COVID-19

\section{PENDAHULUAN}

COVID-19 ditetapkan sebagai penyakit yang menimbulkan wabah [1], melanda 215 negara termasuk Indonesia dengan jumlah meninggal dunia: 3.089 orang [2]. Kondisi tersebut mengharuskan banyak aspek berubah, juga dalam pelaksanaan Latsar CPNS [3]. Di lingkungan Kementerian Keuangan Latsar CPNS secara tatap muka dihentikan dan dimodifikasi dengan pembelajaran daring [4]. Tulisan ini bertujuan untuk menganalisis pembelajaran Whole of Government melalui kelas daring pada latsar from Home dalam masa pandemi COVID-19 di Balai Diklat Keuangan Yogyakarta.

Pengembangan kompetensi PNS dalam bentuk pelatihan nonklasikal dilakukan paling kurang melalui e-learning menggunakan internet secara online dalam Bahasa Indonesia dikenal dengan istilah pembelajaran daring [5]. Pembelajaran daring bersifat limitless, time boundless, whenever, wherever, dan free creativity, diperlukan konsistensi pendidik untuk 
menggunakan jaringan online dan kemampuan menterjemahkan materi ajar menjadi digital yang multi-arah dalam yang akan ditampilkan dalam web yang harus terus menerus dikembangkan [6]. Pertumbuhan e-learning juga dipicu oleh gerakan lifelong learning yang berwujud: 1) kebutuhan untuk terus memperbaharui pengetahuan dan ketrampilan, 2) kebutuhan untuk pelatihan kembali karena konsep satu pekerjaan untuk seumur hidup sudah tidak berlaku lagi, dan 3) kebutuhan dalam menghadapi ledakan informasi di internet. Open and Distance Learning Quality Council di Inggris Raya mendefinisikan e-learning adalah proses pembelajaran efektif yang diciptakan dengan cara menggabungkan konten yang disampaikan secara digital dengan jasa dan sarana pendukung pembelajaran. Ada beberapa terminologi yang berhubungan dengan elearning, yaitu: computer conferencing, telelearning, web-based learning, online learning, virtual classroom, ansynchronous learning, virtual university, distance learning, online tutoring, video conferencing, open learning, distributed education, flexible learning, and blended learning [7].

Penelitian terdahulu tentang pembelajaran daring bagi ASN menunjukkan hal yang positif dan efektif meski ada beberapa catatan perbaikan. Pembelajaran Daring Diklat ASN BPSDM Papua Barat dapat meningkatkan kompetensi atau kemampuan ilmu dan ketrampilan dalam bekerja dan menjadi jawaban terhadap perubahan global government core yang dapat diakses dengan mudah kapanpun dan dimanapun selama terkoneksi ke jaringan internet [8]. Pembelajaran Latsar CPNS secara e-learning cukup efektif dan mampu mendukung proses peningkatan kemampuan peserta dalam memahami beberapa mata pelatihan. Namun perlu upaya optimalisasi mulai dari pembenahan aplikasi elearning, fasilitator pembelajaran, dan waktu pelaksanaan. Selain itu, masih diperlukan adanya pembelajaran klasikal guna pendalaman materi secara efektif karena adanya interaktif antara fasilitator dan peserta. dalam penguatan pemahaman materi. Sehingga metode pembelajaran yang tepat adalah blended learning antara klasikal dan e-learning [9].

Secara umum ada dua hal penting dalam pembelajaran daring agar efektif yaitu: 1) learning object digital yang multimedia, dan 2) learning path yang meliputi learning guide, deskripsi, aktivitas belajar yang dirangkai secara deduktif maupun induktif yang interaktif, menarik dan dapat menghasilkan pengalaman belajar seoptimal mungkin [10]. Pembelajaran blended learning berbasis active learning sangat baik untuk diimplementasikan pada pendidikan tinggi atau universitas. Kriteria utama yang harus dilakukan yaitu: 1) kesiapan fasilitas sistem dan perencanaan yang matang; 2) pengembangan konten yang lengkap dan menarik; dan 3) monitoring dan evaluasi secara rutin pada proses pembelajaran. Namun masih memiliki kelemahan yaitu implementasi pembelajaran aktif masih belum maksimal karena masih perlu proses adaptasi dari dosen dan mahasiswa [11]. Pembelajaran daring dapat meningkatkan kompetensi belajar mahasiswa yang dapat dilakukan melalui tahapan persiapan, pengembangan, pelaksanaan, dan evaluasi, dengan menggunakan pendekatan sistemik [12].

Pembelajaran daring agar komprehensif sebaiknya juga memperhatikan faktor sosial budaya, uraian tugas pendidik dan desainer pembelajaran dengan tahapan eksplorasi, perancangan, dan evaluasi. Agar dapat lebih menarik jika dihubungkan dengan social network misalnya facebook karena perkembangannya yang cukup pesat, user dapat menerima notifikasi melalui akun facebook berupa wall post dan app request [13], e-learning schoology 
[14], WhatsApp [15], dan Google Classroom [16].

Kendala terbesar pembelajaran daring adalah: sinyal kurang bagus [17], selama mengikuti diklat online peserta diberi tugas tambahan [18], masih adanya pembelajar yang kurang paham mengoperasikan aplikasi yang digunakan, keterbatasan kuota, dan gangguan teknis pada media daring [16], dan kurangnya fasilitas di luar lembaga [19]. Pembelajaran daring menjadi pilihan terbaik di masa pandemi COVID-19 [20], yang mengharuskan penerapan social distance [21].

\section{METODE}

Penelitian ini merupakan kuasi eksperimen dengan rancangan eksperimen-post test [22]. Bersifat kualitatif dengan sumber data utama adalah kata-kata, tindakan, dan dokumen [23]. Penelitian ini dilakukan pada Kelas Daring Latsar from Home Golongan II Angkatan II TA 2020 dalam pembelajaran Whole of Government dalam masa pandemi COVID-19 di Balai Diklat Keuangan Yogyakarta pada hari Rabu, tanggal 15 April 2020 dengan peserta sebanyak 30 orang. Data capaian peserta dilakukan dengan evaluasi formatif secara online menggunakan aplikasi Quizizz, sedangkan pendapat peserta tentang kekurangan, kelebihan dan saran perbaikan kelas daring dikumpulkan menggunakan google form setelah setelah pembelajaran daring selesai dilaksanakan. Data yang terkumpul dianalisis secara logiko-induktif yaitu proses berpikir yang menggunakan logika untuk memahami pola dan kecenderungan dalam data melalui tiga tahap yaitu pengkodean, mendeskripsikan karakteristik utama, dan menginterpretasikan data [24]. Hasil penelitian disajikan secara deskriptif.

\section{HASIL DAN PEMBAHASAN}

Sebaran lokasi peserta dari Pulau Jawa tersebar di tiga provinsi yang meliputi sembilan belas kota/kabupaten sebagai berikut: 1) Daerah Istimewa Yogyakarta meliputi Bantul, Kulon Progo, dan Sleman; 2) Jawa Barat meliputi Bandung, Bekasi, Ciamis, Garut, Indramayu, Karawang, Kuningan, dan Subang; 3) Jawa Tengah meliputi Magelang, Pati, Pekalongan, Semarang, dan Sukoharjo; 4) Jawa Timur meliputi Nganjuk, Sidoarjo, dan Tulungagung. Lokasi pembelajar dari luar Pulau Jawa tersebar di tiga provinsi yang meliputi sembilan belas kota/kabupaten sebagai berikut: 1) Kotawaringin Barat di Kalimantan tengah; 2) Mataram di Nusa Tenggara Barat; dan Sambas di Kalimantan Barat. Balai Diklat Keuangan Yogyakarta sebagai pelaksana Latsar From Home dan pengajar melakukan pembelajaran Work From Home yang juga berlokasi di Yogyakarta masuk dalam WIB. Lokasi pembelajar yang juga masuk WIB adalah Jawa Timur, Jawa Tengah, Jawa Barat, Kalimantan Tengah, dan Kalimantan Barat. Sedangkan Nusa Tenggara Barat masuk wilayah WITA yang terdapat perbedaan waktu satu jam lebih dulu.

Pembelajaran kelas daring sangat tergantung dengan kelancaran sinyal internet, kondisi sinyal internet menurut peserta adalah sebagai berikut: 1 atau 3\% yang jaringan internetnya sangat lancar, 14 atau $45 \%$ jaringan internetnya cukup lancar, dan 16 atau $52 \%$ jaringan internetnya lancar. Tidak ada peserta yang jaringan internetnya tidak lancar, sehingga mengganggu proses pembelajaran, juga mereka yang berada di luar Pulau Jawa seperti di Kotawaringin Barat, Mataran, dan Sambas.

Sebelum dilakukan pembelajaran kelas daring, peserta sudah belajar mandiri menggunakan modul yang sudah disiapkan, sehingga saat pembelajaran daring dapat dilakukan pendalaman materi melalui diskusi dengan berpedoman pada 
modul sebagai tindakan kuasi eksperimen. Pilihan kuasi eksperimen juga karena peneliti hanya mengajar pada satu kelas saja. Untuk mengukur capaian tujuan pembelajaran dilakukan post test dengan soal yang dibuat berdasarkan modul dengan nilai rata-rata 92 atau sangat memuaskan dengan perincian sebagai berikut: Bab I Pendahuluan: 80; Bab II Konsep WoG: 96; Bab III Penerapan WoG dalam Pelayanan yang Terintegrasi: 98; Bab IV Best Practices Penerapan WoG di Berbagai Negara: 94, dan Bab V Implementasi WoG dalam Perspektif Kebijakan di Indonesia: 91.

Adapun hasil post test seluruh peserta pembelajaran daring mata pelatihan Whole of Government adalah sebagai berikut: dari 30 peserta 20 peserta atau $67 \%$ mendapat nilai dengan kualifikasi sangat memuaskan, 10 peserta atau $33 \%$ lulus dengan kualifikasi memuaskan. Terdapat 2 peserta dengan nilai sempurna 100, 1 peserta dengan nilai 99, 4 peserta dengan nilai 98. Sedangkan nilai tiga terendah adalah 81, 82, dan 83 masing-masing 1 peserta. Berdasarkan hal tersebut dapat diketahui bahwa metode pembelajaran tersebut berdasarkan capaian hasil post test baik secara rata-rata kelas maupun per peserta secara umum sangat memuaskan. Sedangkan pendapat peserta tentang pembelajaran Whole of Government menggunakan tindakan dan post test adalah sebagai berikut: tidak setuju 1 orang atau $3 \%$, setuju 24 orang atau $77 \%$, sangat setuju 2 orang atau 6\%, dan agak setuju 4 orang atau $13 \%$. Artinya sebagian besar peserta setuju meskipun ada yang berpendapat agak setuju dan juga sangat setuju.

Pendapat peserta pembelajaran tentang berapa besar materi pembelajaran Whole of Goverment dapat disampaikan sesuai modul pembelajaran adalah sebagai berikut: 5 peserta atau $16 \%$ berpendapat tersampaikan $>95 \%$, 15 peserta atau $48 \%$ berpendapat tersampaikan $81 \%-95 \%, 7$ peserta atau $23 \%$ berpendapat tersampaikan $66 \%-80 \%, 4$ peserta atau $13 \%$ bependapat tersampaikan 50\%-65\%. Jawaban terbanyak tindakan pembelajaran tersebut mampu menyampaikan $81 \%-95 \%$, angka ini cukup bagus, namun ada 4 peserta yang berpendapat tersampaikan $50 \%-65 \%$ sehingga perlu dicari alternatif solusinya.

Kekurangan Pembelajaran Kelas Daring Latsar from Home Golongan II Angkatan II TA 2020 dalam pembelajaran Whole of Government dalam masa pandemi COVID19 di Balai Diklat Keuangan Yogyakarta yang paling dominan dalam Pembelajaran Daring Latsar from Home Mata Pelatihan Whole of Government adalah 16 peserta atau $52 \%$ berpendapat kurangnya pemahaman materi. Sebelum tatap muka secara daring peserta sudah ditugaskan melakukan pembelajaran secara mandiri, data ini dapat dijadikan bahan masukan agar dalam melakukan pembelajaran secara mandiri peserta dilakukan post test sehingga sudah diketahui capaian hasil belajar mandiri dan materi pembelajaran apa yang paling banyak dijawab benar maupun paling banyak dijawab salah. Sehingga ketika tatap muka dapat efektif membahas materi-materi yang paling banyak dijawab salah oleh peserta saat belajar mandiri. Untuk kendala internet yang tidak stabil sangat tergantung pada provider yang digunakan di lokasi peserta mengikuti pembelajaran. Adanya clue jawaban kuis karena adanya fitur power up dan redemption pada aplikasi Quizizz. menjadi kekurangan pembelajaran, sehingga selanjutnya fitur tersebut tidak diaktifkan. Melihat nilai hasil evaluasi yang beragam tidak semua peserta memahami atau mempercayai fitur tersebut. Soal post test dibuat sesuai dengan modul yang sudah disiapkan dan dibuat berurutan berdasarkan bab-bab 
dalam modul, sehingga dimungkinkan saat mengerjakan post test peserta menjawab sambil melihat modul. Hal ini masih dalam toleransi karena post test merupakan tes formatif bukan tes evaluasi kelulusan. Sedangkan jawaban waktu post test terlalu cepat karena hanya 2 peserta yang menjawab, dimungkinkan karena belum menguasai materi pembelajaran baik pada saat belajar mandiri maupun tatap muka daring, namun karena berdasarkan hasil nilai post test nilai terendah adalah 81 dengan kualifikasi memuaskan dan batas kelulusan adalah $\leq 60$ dengan kualifikasi tidak memuaskan, maka waktu post test dianggap sudah memadai.

Pendapat peserta tentang kelebihan Pembelajaran Kelas Daring Latsar from Home Golongan II Angkatan II TA 2020 dalam pembelajaran Whole of Government dalam masa pandemi COVID-19 di Balai Diklat Keuangan Yogyakarta adalah sebagai berikut: 25 peserta atau $83 \%$ berpendapat metode pembelajaran tersebut menarik. Pembelajaran ini menarik karena menyenangkan, tidak membosankan, lebih mudah untuk mengingat materi karena terdapat soal yang dimunculkan berulang kali. Selain itu juga dapat mengasah kecekatan diri dalam mencari dan menemukan jawaban, memudahkan peserta juga dalam memahami materi seperti tentang jenis dan bentuk $e$ government, lebih menantang dan seru karena bisa melatih untuk membaca dan berfikir cepat. Sedangkan 5 peserta atau $17 \%$ berpendapat efektif dan efisien dikarenakan pembelajaran yang mudah diakses, lebih praktis dan fleksibel.

Peserta memberikan saran perbaikan beragam saran perbaikan yang diajukan peserta terbesar 14 peserta atau $47 \%$ berpendapat agar menambah pembahasan. Peserta menyatakan tidak semua peserta dapat memahami kuis dan menjawab dengan sempurna, kemampuan menjawab peserta berbeda beda, oleh karena itu ada baiknya jika setiap pertanyaan dibahas lebih rinci dan mendalam kembali, pada akhirnya soal tidak hanya untuk dijawab, namun untuk dibahas bersama-sama. Selain itu beberapa soal dalam bentuk jawaban benar salah dipandang kurang tepat oleh peserta, sebaiknya dalam bentuk pilihan ganda dengan jawaban lebih dari dua. Saran perbaikan ini harus mendapat perhatian untuk pembelajaran berikutnya, agar pembelajaran daring lebih efektif dengan pembahasan materi yang lebih banyak.

Altenatif solusi yang dapat dilakukan adalah dengan melakukan tes formatif saat peserta melakukan belajar mandiri sehingga saat pembelajaran daring sudah dapat diketahui materi yang paling banyak dijawab salah oleh peserta, karena materi dan jam pembelajaran sudah ditetapkan, maka metodenya yang harus dilaksanakan dengan metode yang paling efektif. Terdapat 5 peserta atau $17 \%$ berpendapat pembelajaran sudah baik. Terdapat 5 peserta atau $17 \%$ memberi saran perbaikan agar waktu kuis perlu disesuaikan karena waktu yang disediakan untuk menjawab soal post test adalah duapuluh detik. Namun jika dilihat dari nilai post test paling rendah adalah 81 dengan kualifikasi memuaskan maka saran untuk menambah waktu dapat diabaikan, karena waktu tersebut membuat peserta berpikir cepat dan membuat pembelajaran menarik saat mengerjakan post test secara online. Selanjutnya, terdapat 3 peserta atau $10 \%$ yang menyarankan untuk mengurangi kuis, karena kuisnya terkesan terlalu banyak, peserta juga meminta sebaiknya kuis hanya 10 soal saja. Saran perbaikan ini layak dipertimbangkan, altenative solusinya agar jumlah soalnya sedikit namun masih tetap mencakup semua materi adalah dengan membuat soal menjadi pilihan ganda dengan jawaban lebih dari dua. Selanjutnya terdapat masing-masing 1 
peserta atau 3\% yang berpendapat sudah baik, menghilangkan fitur power up dan redemption dalam aplikasi quizizz, menyarankan sebaiknya pembelajaran lebih membahas pada implementasi di lapangan pekerjaan, pemberian soal dan kunci jawaban agar peserta dapat mempelajari kembali soal-soal dalam kuis tersebut di luar pembelajaran, saran tersebut akan menjadi perbaikan pembelajaran berikutnya. Secara umum pembelajaran daring dinilai positif dan efektif oleh peserta sehingga pembelajaran kelas daring dapat dilanjutkan baik pada masa pandemi maupun menjadi new normal.

\section{SIMPULAN}

Pembelajaran Kelas Daring Latsar from Home Golongan II Angkatan II TA 2020 dalam pembelajaran Whole of Government dalam masa pandemi COVID-19 di Balai Diklat Keuangan Yogyakarta diikuti oleh peserta dari dua puluh dua kota atau kabupaten dari tujuh provinsi. Kelas daring tergantung dengan internet, sebagian besar jaringan internetnya lancar. Peserta sebelum tatap muka secara daring sudah belajar mandiri, saat tatap muka dilakukan pendalaman materi dengan diskusi daring kemudian dilakukan post test. Hasil nilai post test rata-rata kelas adalah 92 atau sangat memuaskan, sedangkan nilai per peserta tertinggi dengan nilai 100 dan terendah 81 atau memuaskan, batas nilai minimal adalah $\leq 60$. Tindakan atau eksperimen pembelajaran mampu menyampaikan materi sampai 81\%-95\%.

Kekurangan Pembelajaran Kelas Daring Latsar from Home mirip dengan pembelajaran daring dalam penelitian terdahulu kendala internet yang tidak stabil, namun karena dilaksanakan secara blended learning juga ada kendala pada saat tahap belajar mandiri. Sedangkan kelebihannya berbeda dengan penelitian terdahulu, khususnya penggunaan aplikasi
Quizizz karena lebih menarik, menyenangkan, mengasah kecekatan diri dalam mencari dan menemukan jawaban. Peserta memberi saran perbaikan agar menambah pembahasan materi pembelajaran, bentuk soal dengan pilihan jawaban benar-salah diganti pilihan ganda, dan mengurangi jumlah soal post test. Secara umum pembelajaran daring dinilai positif dan efektif oleh peserta sehingga dapat dilanjutkan baik pada masa pandemi maupun menjadi new normal.

\section{UCAPAN TERIMA KASIH}

Ucapan terimakasih penulis sampaikan kepada seluruh peserta Pembelajaran Kelas Daring Latsar from Home Golongan II Angkatan II TA 2020 dalam pembelajaran Whole of Government dalam masa pandemi COVID-19 yang bersedia meluangkan waktu mengisi kuesioner setelah pembelajaran berlangsung, serta Pimpinan dan jajaran pegawai Balai Diklat Keuangan Yogyakarta.

\section{DAFTAR PUSTAKA}

[1] Keputusan Menteri Kesehatan Nomor:

HK.01.07/MENKES/104/2020,

Penetapan Infeksi Corona Virus (Infeksi COVID-19). 2020.

[2] G. T. P. P. COVID-19. "Data Sebaran". BNPB, 2020, [Online] Tersedia: https://covid19.go.id/.

[3] Surat Edaran Nomor: 10/K.1/HKM.02.3/2020. Panduan Teknis Penyelenggaraan Pelatihan dalam Masa Pandemi Coronavirus Disease (COVID-19). 2020.

[4] S. E. N. SE-2/PP/2020. Tindak Lanjut Upaya Pencegahan Penyebaran COVID-19 di Lingkungan BPPK. 2020.

[5] Peraturan Pemerintah Nomor 11 Tahun 2017. Manajemen Pegawai Negeri Sipil. 2017.

[6] M. A. Rahman, R. Amarullah, dan K. Hidayah. "Evaluasi Penerapan Model 
Pembelajaran E-Learning pada Pelatihan Dasar Calon Pegawai Negeri Sipil". J. Borneo Adm., vol. 16, no. 1, pp. 101-116, 2020, doi: 10.24258/jba.v16i1.656.

[7] A. Kurniawan, S. Siahaan, dan J. Pusat. "Kontribusi Diklat Online terhadap Calon Pejabat Online Training Contribution To the Functional Official Candidates of Instructional Designers". J. Teknodik, vol. 20, no. 1, pp. 121129, 2016.

[8] U. A. Chaeruman. "Alur Belajar: Meningkatkan Interaktivitas Pembelajaran Daring". Seminar \& Lokakarya Pembelajaran Daring di Perguruan Tinggi, pp. 1-10, September 2017.

[9] R. Setiawan, D. Mardapi, A. Pratama, dan S. Ramadan. "Efektivitas Blended Learning dalam Inovasi Pendidikan Era Industri 4.0 pada Mata Kuliah Teori Tes Klasik". J. Inov. Teknol. Pendidik., vol. 6, no. 2, pp. 148-158, 2019, doi: 10.21831/jitp.v6i2.27259.

[10] S. Wahyuda dan M. Diningrat. "Desain Model Pembelajaran Online". J. Pendidik. Terbuka dan Jarak Jauh, vol. 20, no. 1, pp. 17-24, 2008 , doi: 10.33830/ptjj.v20i1.333.2019.

[11] L. Sofyana dan A. Rozaq. "Pembelajaran Daring Kombinasi Berbasis Whatsapp pada Kelas Karyawan Prodi Teknik Informatika Universitas PGRI Madiun". J. Nas. Pendidik. Tek. Inform., vol. 8, no. 1, p. $\quad 81, \quad 2019, \quad$ doi: 10.23887/janapati.v8i1.17204.

[12] A. Yuhdi dan N. Amalia. "Desain Media Pembelajaran Berbasis Daring Memanfaatkan Portal Schoology pada Pembelajaran Apresiasi Sastra”. Basastra, vol. 7, no. 1, p. 14, 2018, doi: 10.24114/bss.v7i1.9320.

[13] K. Mukharomah, U. G. Mada, dan N.
Qomariyah. "Penggunaan Analitik Hirarki Proses dalam Menentukan Preferensi Platform Pembelajaran Daring Selama Masa Tanggap Darurat Covid-19 pada Mahasiswa UGM Yogyakarta". Edutech, vol. 1, no. 2, pp. 1-10, 2020, doi: 10.13140/RG.2.2.11562.98248.

[14] A. Meiza, F. S. Hanifah, Y. Natanael, dan F. S. Nurdin. "Analisis Regresi Ordinal untuk melihat Pengaruh Media Pembelajaran Daring terhadap Antusiasme Mahasiswa Era Pandemi Covid". 2020.

http://digilib.uinsgd.ac.id/30730/1/art ikel\%20KTI\%20final\%20asti\%20dk k.pdf

[15] T. Darmayanti, M. Y. Setiani, dan B. Oetojo. "E-Learning pada Pendidikan Jarak Jauh: Konsep yang Mengubah Metode Pembelajaran di Perguruan Tinggi di Indonesia". $J$. Pendidik. Terbuka dan Jarak Jauh, vol. 8, no. 2, pp. 99-113, 2007.

[16] R. C. Chick, et al. "Using Technology to Maintain the Education of Residents During the COVID-19 Pandemic". J. Surg. Educ., vol. 00, no. 00, pp. 1-4, 2020, doi: 10.1016/j.jsurg.2020.03.018.

[17] A. Purmadi, M. Samsul Hadi, dan L. Najwa. "Pengembangan Kelas Daring dengan Penerapan Hybrid Learning Menggunakan Chamilo pada Matakuliah Pendidikan Kewarganegaraan Developing Daring Class With Hybrid Learning Application Using Chamilo on Civics Education Courses". J. Edcomtech, vol. 3, no. 2, pp. 135-140, 2018.

[18] L. Dewi. "Rancangan Program Pembelajaran Daring di Perguruan Tinggi: Studi Kasus pada Mata Kuliah Kurikulum Pembelajaran di Universitas Pendidikan Indonesia". Edutech, vol. 16, no. 2, p. 205, 2017, doi: 10.17509/e.v16i2.7616. 
[19] A. S. Syarifudin. "Impelementasi Pembelajaran Daring untuk Meningkatkan Mutu Pendidikan sebagai Dampak Diterapkannya Social Distancing". J. Pendidik. Bhs. dan Sastra Indones. Met., vol. 5, no. 1, pp. 31-34, 2020, doi: 10.21107/metalingua.v5i1.7072.

[20] D. R. A. U. Khasanah, H. Pramudibyanto, dan B. Widuroyekti. "Pendidikan dalam Masa Pandemi Covid-19”. J. Sinestesia, vol. 10, no. 1, pp. 41-48, 2020.

[21] W. Darmalaksana, R. Y. A. Hambali, A. Masrur, dan Muhlas. "Analisis Pembelajaran Online Masa WFH Pandemic Covid-19 sebagai
Tantangan Pemimpin Digital Abad 21 ”.

2020.

http://digilib.uinsgd.ac.id/30434/1/11 042020.pdf

[22] J. Creswell. Riset Pendidikan, Perencanaan, Pelaksanaan, dan EValuasi Riset Kualitatif \& Kuantitatif, Kelima. Jakarta: Pustaka Pelajar, 2015.

[23] L. J. Moleong. Metodologi Penelitian Kualitatif. Bandung: Remaja Rosdakarya, 2015.

[24] A. Mertler. Action Research Mengembangkan Sekolah Memberdayakan Guru. Yogyakarta: Pustaka Pelajar, 2011. 